\title{
VALUE PURSUIT OF CHINESE PUBLIC CULTURAL GOVERNANCE IN THE NEW ERA
}

\author{
Jian Cheng ${ }^{1}$ and Zhili Chen ${ }^{2}$ \\ ${ }^{1}$ Human Resources and Social Security Bureau, Qinhuai District, Nanjing, China \\ ${ }^{2}$ School of Marxism, Hohai University, Nanjing, China
}

DOI: 10.46609/IJSSER.2021.v06i01.014 URL: https://doi.org/10.46609/IJSSER.2021.v06i01.014

\begin{abstract}
Chinese public culture governance deepens cultural identity by improving the theoretical system of socialist cultural thoughts with Chinese characteristics, exploring and innovating the spiritual wealth of Chinese culture, and promoting people's cultural participation. This governance also continuously develops socialist culture with Chinese characteristics, promotes the high-quality development of cultural undertakings and cultural industries, cultivates new people of the times, and promotes the new style of the times, thereby shaping cultural confidence. On this basis, Chinese public cultural governance is committed to innovating a set of value mechanisms to promote the coordinated development of the people's cultural identity and cultural selfconfidence in thought and behavior, and realize the formation of a value community through dynamic construction. As a result, the value pursuit of public cultural governance in the new era is presented.
\end{abstract}

Keywords: Public cultural governance; Value pursuit; Cultural identity; Cultural confidence

\section{Deepening Cultural Identity of China in the New Era}

Chinese people's consensus and recognition of their mainstream culture is an important foundation for maintaining the development of Chinese culture. Therefore, the establishment of a broad cultural identity has become a key task in the construction of Chinese culture.

First, Public cultural governance should guide the direction of cultural identity by constantly improving the theoretical system of socialist cultural thoughts with Chinese characteristics. On the one hand, the governance should allow Marxist cultural theory to provide theoretical guidance for paving the Chinese road of socialist cultural identity in the process of continuous sinicization. The cultural development concepts promoted by Mao Zedong Thought, Deng Xiaoping Theory, Three Represents Theory, the Outlook of Scientific Development and Xi 


\section{International Journal of Social Science and Economic Research}

ISSN: $2455-8834$

Volume:06, Issue:01 "January 2021"

Jinping Thought on Socialism with Chinese Characteristics for a New Era are in the same line. They all follow the dialectical thinking of Marxism-Leninism to integrate Chinese and Western cultures, and use the theoretical system of scientific socialism to guide the creative transformation of Chinese culture, so that the level of cultural development in our country matches the era. The outstanding achievements and fruitful results of the construction of socialist culture with Chinese characteristics have successfully confirmed that Marxist Concept of Culture and theory of practice are the theoretical magic weapon to guide the rejuvenation of the Chinese culture and consolidate the cultural identity of the Chinese people. On the other hand, Public cultural governance should implement the core socialist values into the Chinese cultural construction thoughts, and make them the quintessence of Chinese cultural identity.

Second, public cultural governance should expand cultural identity by exploring, inheriting, innovating and propagating the spiritual wealth of Chinese culture. According to the development characteristics of the new era, the governance should provide the public with a comprehensive and objective vision of world culture through the communication of multiple media, so as to accumulate spiritual strength for the Chinese cultural identity. In this process, the cultural crisis can be transformed into an important opportunity to reconstruct the national cultural identity by shaping the people's value judgment of contemporary culture.

Third, public cultural governance should allow the majority of the people to deepen their cultural identity in the practice of systematic cultural participation. In this process, the public will gradually sublimate from perceptual to rational cognition of the cultural thought on socialism with Chinese characteristics, and then naturally internalize it in their hearts. As a result, the cultural thought on socialism with Chinese characteristics will get a strong response in the continuous deepening of the public's cultural identity. On this basis, the practice of the socialist cultural theory with Chinese characteristics that is advancing with the times will interact with the spiritual and cultural practices of the people, thereby nurturing the advanced socialist culture of the new era that is consciously recognized by members of the society, and allowing the Chinese people to construct self-identity through continuous absorption of the spiritual nutrition of this culture.

\section{Strengthening the Cultural Confidence of China in the New Era}

In the Chinese context, cultural confidence shows the people's cultural beliefs established by the cognition and identification with the historical traditions, value connotations and practical significance of the party, state and national culture. According to this requirement, public cultural governance should "closely focus on the mission of raising the banner, gathering people's hearts, cultivating newcomers, invigorating culture, and exhibiting image." [1] 


\section{International Journal of Social Science and Economic Research}

ISSN: $2455-8834$

Volume:06, Issue:01 "January 2021"

First, public cultural governance are supposed to develop the socialist culture with Chinese characteristics that has lofty values and spiritual pursuits. The socialist culture with Chinese characteristics represents a crystallization of the creative wisdom of Chinese excellent traditional culture, revolutionary culture and advanced socialist culture. Its ultimate goal of socialist culture with Chinese characteristics is to cultivate localized spiritual soil for the realization of people's free and all-round development. Therefore, China urgently needs to awaken the public consciousness and concept rationality in modern society through the socialist culture with Chinese characteristics as the dominant culture. Based on this, public cultural governance needs to create a noble quality for socialist culture with Chinese characteristics that transcends the utilitarian value logic of liberal market economy, and establish value authority for the people's ideology and belief.

Second, public cultural governance should provide a solid backing for cultural confidence by promoting the high-quality development and lasting prosperity of cultural undertakings and industries. The rejuvenation of the Chinese nation is not only the rejuvenation of the nation, but also the rise of the Chinese civilization. The cultural self-confidence revealed from it is not a blind self-confidence. It is supported by a strong national cultural soft power and Chinese cultural influence. The reason why Chinese culture can become a realistic force with unique charm to shape the social development of China and even the world is that this profound culture has the outstanding characteristic that not only allow "self" to identify, but also convince "others". Entering the new era, public cultural governance needs to promote this excellent characteristic of Chinese culture. According to the strategic plans, fundamental principles and practical needs of developing a great modern socialist country, public cultural governance needs to encourage socialist civilization to achieve phased and historic leap, and promote the socialist national governance system with Chinese characteristics to "play the role of culture in guiding the fashion, educating the people, serving the society and promoting development." [2]

Third, public cultural governance must cultivate new people of the times and promote the new style of the times. Specifically, the governance should use cultural confidence to continuously enhance political identity, ideological identity and emotional identity. The governance needs to strengthen the consciousness of the need to maintain political integrity, think in big-picture terms, uphold the leadership core, and keep in alignment, and fortify confidence in the socialist path, theories, system and culture. [3] The governance must boost the morale of the masses and renew the social atmosphere.

\section{Promoting the High-Quality Collaborative Development of Cultural Identity and Cultural Confidence}




\section{International Journal of Social Science and Economic Research}

ISSN: $2455-8834$

Volume:06, Issue:01 "January 2021"

Chinese cultural governance in the new era should focus on improving and innovating the mechanism of national identity in the field of mainstream ideology, cultural life and cultural production, and promote cultural identity and cultural confidence to become an important representation of Chinese cultural construction concepts and development strategies.

First, public cultural governance should integrate the values of cultural identity and cultural confidence into a national cultural belief system with rigorous reasoning logic. In the final analysis, the core competitiveness of a country lies in the ability and spiritual cultivation of the Chinese people. Therefore, the fundamental task of national cultural construction lies in enlightening the people and inspiring their hearts. Especially in the international competition pattern of the post-COVID era with changing situation and surging current, China needs to train the people's critical thinking on Chinese and Western cultures and diverse ideological trends. China needs to encourage people to firmly regard the identification and confidence of Chinese culture as a lifelong cultural belief in the enlightenment and edification of the mainstream culture. China needs to encourage people to become wise, upright and competent, and shoulder the original aspiration and mission of seeking happiness for the Chinese people and rejuvenation of the Chinese nation. In this regard, public cultural governance should provide cultural identity and cultural confidence with a set of value measurement mechanisms that are inherited and conceptualized, and jointly shape the ideology of Chinese people.

Second, public cultural governance should promote the people to reflect the sense of cultural identity and cultural confidence from inside to outside in their thoughts and behaviors. The people's strong sense of identity with the national mainstream culture, which takes the socialist core values as the cornerstone of the national spirit, is an important psychological support for their firm belief in the national cultural values and development outlook.

Third, public cultural governance should construct the overall identity in the dynamic construction process of both initiative and vanguard. In this way, the governance should cultivate deep and lasting national quality, and carve out an enduring cultural community. Finally, the governance needs to make the majority of the people condense into a closely united community of destiny under the cultural inspiration, and make China become the ultimate value community of national development with strong soft power.

\section{References}

[1] Jinping, Xi. Speech at the celebration of the 40th anniversary of reform and opening-up. Beijing: People's Publishing House, 2018. 
International Journal of Social Science and Economic Research

ISSN: 2455-8834

Volume:06, Issue:01 "January 2021"

[2] Changchun, Li. The Road to a Cultural Power: Exploration and Practice of Cultural System Reform. Beijing: People's Publishing House, 2013.

[3] Ruifeng, Chen. Promoting the high-quality development of the construction of a civilization practice center in the new era. Study Times, 2020. 